\title{
A Window of Opportunity? Preliminary Thoughts on Women's Sport in Post- war Britain
}

\author{
Joyce Kay \\ University of Stirling
}

On 6 May 1954, in a specially staged and filmed event, Roger Bannister became the first athlete to run a mile in less than four minutes, with the help of 'pacemakers'. Three weeks later, in a genuine race at the Midland Women's AAA championships, Diane Leather became the first woman to run the same distance in under five minutes, without pacemaking assistance and without any of the subsequent kudos, hyperbole and world-wide acclaim. Bannister, now Sir Roger, became a sporting legend and the subject of a 150-page special issue of Sport in History in which every conceivable aspect of his feat - its cultural and historical significance, the notion of the record, and issues of image, scientific training and the use of drugs - was dissected and discussed by eight men... and one woman. [1] Who recalls Leather?

When current Olympic swimming champion Rebecca Adlington and her team mate Joanne Jackson both swam inside the world record time during the same race in March 2009, they were the first British women to achieve this double since 1956.

Adlington had become an instant heroine of sport after her double gold medal triumph in 2008, was voted into third place behind triple Olympic gold medallist Chris Hoy in that year's BBC Sports Personality of the Year contest and was awarded an OBE in the New Year's Honours list. [2] Yet the record breakers of 1956, Olympic gold and bronze medallists Judy Grinham and Margaret Edwards, are scarcely remembered today in spite of subsequent impressive careers and press acclaim at the time: The Times, for example, had hailed 'Miss Grinham's Back-stroke Triumph' when she won gold in Melbourne. [3] She was Britain's first Olympic swimming champion since 1924 and the first swimmer to hold Olympic, European and Commonwealth titles in the same event simultaneously. However, unlike Adlington, she only received a belated MBE in 2007, after a lengthy campaign to recognise her performance.

These examples serve to illustrate several issues: the undervaluing of women's achievements when compared with men, particularly within written history; the instant celebrity status of the successful twenty-first century athlete; and the way in which Britain's sporting heroines of the post-war era have often been overlooked, even though the two decades from 1948 were particularly fruitful for British sportswomen. Much academic attention has focused on the constraints prevalent in women's sport - often a legacy of the medical debates of the Victorian era - and emphasis placed on the negative attitudes of the (largely) tabloid and right-wing press, in spite of evidence that the success of Britain's female athletes was suitably acknowledged and celebrated in the post-war decades both in the media and amongst the general public.[4] The following paper will attempt to rescue their sporting record from relative obscurity and will begin to challenge some of the accepted wisdom regarding sport and gender in twentieth-century Britain. Focusing largely on elite athletes and utilising previously under-researched sources it will argue that the many successful sportswomen provided a variety of sporting role models for girls during the 1950s and early 1960s. Instead of dwelling on negative aspects of women's sport and reiterating theories of masculine cultural hegemony, separate spheres and the media construction of sport it will show that in many instances women just 'got on with the 
job', paid little heed to outdated attitudes and opinions and, like Olympic medallists Dorothy Hyman and Anita Lonsbrough, were acknowledged by press and public alike. [5] That the success and relatively high profile of women's sport in this period seemed to fade away in the 1970s is a matter of concern and an issue for future discussion.

\section{Accentuating the positive}

The success of British sportswomen in the post-war period is remarkable. In the four Olympiads from London 1948 to Rome 1960 women constituted less than 15 per cent of the British team but brought home 30 per cent of the medals. [6] If the Olympic events in which women were barred are discounted from the total - for example, boxing, rowing, sailing and athletic races over $200 \mathrm{~m}$ - they were more successful than their male counterparts, winning seven medals to one in swimming and diving competitions and sixteen to fourteen in athletics. Between 1955 and 1969 British women won seven Grand Slam tennis singles titles; the nation still awaits its first post-war male champion. [7] In equestrian sport, Sheila Willcox and Anneli Drummond-Hay were instrumental in forcing the International Olympic Committee (IOC) to admit female competitors to the Olympic three-day event. [8] Willcox won the prestigious Badminton Horse Trials - open to both genders - in three consecutive years 1957-59. Drummond-Hay won it in 1962, before embarking on a successful career in international showjumping. [9] In the same discipline Pat Smythe and Marion Coakes won Olympic medals as British team members in the fifties and sixties. Beryl Burton was a world champion cyclist five times between 1959 and 1966; twins Diane and Rosalind Rowe won the world table tennis championship twice in the 1950s. [10] In Curtis and Wightman Cups - women's golf and tennis team competitions against the United States - British golfers recorded more successes in the fifties than in the subsequent twenty years and Britain's tennis players performed creditably from 1958-68 before total American domination brought an end to the tournament in 1989. [11]

Yet, with the exception of fleeting references in Holt and Mason's Sport in Britain 1945-2000, there has been little scholarly attention to women's progress in this period. [12] After concentrating on Victorian and Edwardian attitudes to women and sport, academics have made brief mention of the difficulties encountered by female footballers and would-be Olympians in the twenties and then skipped straight to the early 1970s, presumably on the grounds that no fundamental changes occurred in the intervening period. [13] Historians are guiltier of this neglect than the media, the usual scapegoats of feminist writers: some members of the press, in particular, both recognised and sponsored female sport in the interwar and post-war eras. At the elite level, the Sporting Record (1952) and the Sports Journalists' Association (1959) showed appreciation for sportswomen in their annual awards. The Daily Mirror sponsored an important inter-club women's athletics meeting as early as 1925; the publishers of Girl and Eagle magazines organised a table tennis competition for girls and boys in the 1950s; and the specialist magazine Golf Illustrated ran tournaments in which women competed during the 1920s. In the present century, the media have made efforts to resurrect the ground-breaking success of post-war heroines. BBC Radio 4 ran a feature on Diane Leather's five-minute mile; the Guardian, as part of a celebration of the 2012 London Olympics bid, interviewed equal numbers of male and female athletes who had taken part in the 1948 Games. [14] 
Whilst an analysis of column inches given over to coverage of women's events would undoubtedly produce a small percentage in comparison with men's, there is plenty of positive comment about female sport. The Times heaped much praise on women's athletics 'which now often contribute handsomely to the bigger meetings.' [15] In 1955, although at the end of a long article on the men, it highlighted 'the British women who for some time have served their country so well in international athletics' and noted that 'they really deserve much more than a passing reference to their abilities.' [16] A report on the British women's championships which saw a world record, a world best performance and three British records ended, 'It surely must be the final answer to those who have advocated sending only a small women's team to Melbourne.' [17] Female swimmers were also appreciated. When Anita Lonsbrough won gold in the $200 \mathrm{~m}$ breaststroke at the Rome Olympics, the Daily Telegraph commented that 'Miss Lonsbrough not only broke the world record but carried out with wonderful composure and self-discipline what cannot have been an easy plan'. Prior to this in 1956 it quoted the manager of the British team after Judy Grinham and Margaret Edwards had triumphed in the pool: 'there is no easy road nowadays either to Olympic representation or to an Olympic medal ... but these girls have done it and are an example to British swimmers.' [18] Britain's gold medal winning fencer in Melbourne, Gillian Sheen, was described as having 'nerves of steel', while showjumper Pat Smythe received many plaudits, from 'Miss P. Smythe ... has no superior' to 'one can only regret the arbitrary rule which debars Miss P. Smythe and Tosca'. [19]

Not one of these newspaper articles trivialises the achievements of the athletes by mentioning their domestic skills, their families or boyfriends, or any other aspect of their personal lives which are said to typify the reporting of women's sport in more recent times. Perhaps a more balanced view of the media would be reached by focusing attention on the 'quality' British press in the 1950s instead of the mass circulation, conservative, populist dailies. An impression that the sexualisation of female athletes and the objectification of the female body are far less noticeable in the post-war era also deserves further study. [20]

\section{Sport and gender in the post-war era: girls' comics and women's magazines}

A more familiar aspect of gendered media representation can be found in the traditional women's and children's press. There have been several academic studies of both genres but few have focused specifically on sports content and those that have dealt with the 1970s and 1980s. [21] Mary Dunne's analysis of junior (up to age 10) and teen publications found that the positive characteristics linked with sport in the younger comics - dedication, team spirit and perseverance - changed to negative associations in the older magazines which concentrated almost exclusively on personal appearance and relationships with boys. [22] But was this the case in the post-war decades? In the 1950s there was a more limited range of magazines to choose from but one of the most popular was Girl, categorised as a 'secondary schoolgirl' paper in contrast to the illustrated story-strip style elementary school comic, and probably appealing to an age range of 10-14. [23] It came from the same publishing house as the Eagle comic for boys; both were said to have adopted a 'high moral tone' and were slightly more expensive than their rivals, the result of good quality colour printing on glossy paper. Nevertheless, at its peak Girl had a circulation 
of around 650,000, a substantial figure at a time when the estimated female population of 10-14 year olds was roughly $1.6 \mathrm{~m}$. [24]

Although it has been chided for featuring fictional heroines who conformed to an asexual adolescent ideal - graphically referred to by Dunne as at 'the tadpole stage' - Girl undoubtedly set out to inform and to extend horizons. [25] A Girl Adventurers' Club was launched offering all kinds of expeditions, outings, visits and holidays: membership reached 16,000 in the first six weeks. More risky for its time was the problem page. Letters poured in on a range of subjects including requests for information about sexual development and child sex abuse which were dealt with separately by an educational psychologist. This does not suggest the cosy, idealised, traditional notion of girlhood usually depicted in the post-war girls' magazines although no discussion of such taboo subjects ever appeared in the paper. [26] There is also evidence of gender crossover in the readership of Girl and Eagle. After Girl ran its first painting competition in 1954, the editor claimed that he had received 'so many pathetic letters from boys' that it was extended to include readers of Eagle. Girls were also known to be reading the boys' comic before the launch of 'their own', gender specific version and continued to win prizes in Eagle competitions. [27] This should only be surprising to those who still believe that boys and girls inhabited separate spheres in the mid-twentieth century. When Dominic Sandbrook noted that girls were 'not expected' to enjoy the belligerence and rowdiness of boys' comics and that they chose instead from a range of their own, whose expectations does he have in mind and is he sure that girls were not reading magazines bought for or by their brothers'? [28] Why are academics so willing to believe that a whole generation of girls and young women simply lapped up the fare that was offered them, indeed, were indoctrinated by it?

In addition to the weekly comics, there was also an Eagle Annual, a yearly Eagle Book of Sport and a Girl Annual, produced for the Christmas market from 1953 until 1965 when its style was made redundant by the changing society of the 'swinging sixties'. Although such books were 'usually seen as more anodyne than the comics', because they were often given as gifts by adults whose approval had to be won, there seems to have been little obvious 'watering-down' of the general content. [29] There was no 'problem' section in Girl Annual but the regular illustrated strips of the weekly paper - Belle of the Ballet, Claudia of the Circus, and other heroines, usually in the shape of nurses and schoolgirls - were ever-present, together with short stories, hobbies, and, according to the contents page of volume 1, 'real life adventures, interest, puzzles and sport.' (my italics).

An analysis of ten volumes of Girl Annual spanning the years 1953-1962 provides an interesting insight into the depiction of sporting activities for girls in this period. Although Morris states that 'on the whole, sport did not feature strongly' in the weekly comic, this cannot be said of the annuals which contained several articles in every edition. [30] Some were about successful female sports stars - the first issue included items on Jeanette Altwegg, British gold medal ice skater at the 1952 winter Olympics and the Rowe twins who had recently won their first world championship. Others offered tips on conventional sports such as tennis, diving, swimming and horse riding, the so-called 'aesthetically pleasing' and appropriate activities for girls. A third group, however, featured more challenging pursuits - sailing, motor racing and rock-climbing - and it is fascinating to see how positively these were portrayed. 
But isn't it (rock-climbing) a game for men and boys only? Not a bit of it! Thousands of girls graduate from mountain-walking to rock-climbing, and one of Britain's most famous climbing clubs, the Pinnacle Club, excludes male members altogether... Women have shown themselves the equal of men in every branch of the sport. [31]

The item then went on to explain basic techniques and provide information about how to find a beginners' course in rock-climbing and mountaincraft. Another article entitled 'Queens of Speed', subtitled 'girls have shared the laurels of motor racing since it started', showcased the exploits of female rally drivers such as Pat Moss (sister of racing driver Stirling Moss) and Sheila Van Dam and ended, 'so don't let anyone tell you that motor racing is exclusively a man's game.' The authors of these and most other sporting articles were men; regular contributor Kenneth Wheeler penned many sports items for both Girl and Eagle as well as editing a book on the life of tennis player Christine Truman. [32]

Although traditional careers - 'do you want to be a nurse/nannie/air stewardess/ kennel maid?' - and gentle female hobbies such as embroidery, leaf printing and pottery often figured in Girl Annuals, they were balanced by pieces about female vets, iconic women like Emmeline Pankhurst and leisure pursuits such as camping and parachuting. 'Women of Action' included showjumper Pat Smythe, pioneer aviator Jacqueline Cochrane and underwater explorer Lotte Haas. [33] Of special significance are the illustrations on front and back inside covers, almost invariably featuring sporting activities. Mixed groups of teenagers, with an emphasis on girls, are shown taking part in tennis, skating, cricket, skiing, swimming, running, showjumping, sledging, sailing and other water sports. There is no female passivity or 'standing on the touchlines' here, unlike the situation outlined by Dunne for the later era. [34] Fictional characters are portrayed as 'independent, assertive and resourceful individuals', more typical of the junior comics of the 1980s; by then, however, adolescent magazines were viewing sport and physical activities in a negative light. [35]

Features on female athletes are very revealing of 1950s attitudes to sport, and apparently endorsed the high moral values referred to earlier. Whatever the discipline and whoever the 'star' - tennis player Ann Haydon, swimmer Anita Lonsbrough, Olympic bronze medal-winning sprinter June Foulds, or table tennis world champion Helen Elliott - the same phrases are endlessly repeated: 'hard work', 'patience', 'courage and determination', and 'dedication'. There is also little to support the standard academic view that girls were 'naturally' less aggressive and competitive than boys. [36] The 1954 annual has June Foulds stating that only a very few sports are unsuitable for girls; in 1958 Margaret Edwards, bronze medallist in the 100m backstroke at the 1956 Olympics was quoted as saying 'I swim only to win if I can ... winning is what matters most.' [37] These statements are replicated in the autobiographies of successful British tennis players. Christine Truman, winner of the French women's singles title in 1959 and runner-up at Wimbledon in 1961, commented, 'as soon as I started lawn tennis, I wanted to be really good. I could never see any point in just playing for a hit and a giggle.' Virginia Wade, the last British winner of a Wimbledon singles' title, talking about her childhood in South Africa, said, 'little girls' games were sweet and more aesthetically attractive than the 
vigorous athletic ones, but they couldn't keep me involved for any length of time. Somehow there was more urgency to play the active games.' [38]

The Girl article on Margaret Edwards is particularly interesting as it incorporates two different views of the female sports star. It is entitled " Try Again" Margaret ... Olympic swimmer - and schoolgirl.' Readers are told that 'her schoolmates know her as a jolly good sport - good at all games' but, to emphasise her 'girl next door' appeal, are also informed that she likes knitting and sewing. They are reminded that the young backstroke champion was first introduced to them in Girl Weekly during 1953 as an outstanding British hope. 'She did not let us down' intones the author pompously before trying to show how her relative failure at the 1956 Games served to act as a spur to future success. 'That's why she's "Try Again Margaret"'. [39] She did try again. In an international career spanning seven years, she held the $100 \mathrm{~m}$ backstroke world record three times but was always eclipsed by rival Judy Grinham at the major championships. Although aspects of the feature in Girl display a more typical feminine dimension, this is balanced throughout by an emphasis on competition, courage and determination.

A study of Girl Annual suggests that many of the negative aspects of sport found in later twentieth-century girls' magazines are not present in this popular publication of the 1950s and early 1960s. 'Success, competitiveness, mental and physical aggression, training and dedication', all said to be archetypal 'masculine' values associated with sport, are there in abundance. Successful female role models are showcased, a wide range of sporting activity is introduced and women are depicted as equal to men in many areas. Furthermore, it must be presumed that the adults who bought the annuals approved of the contents even though these stories and articles undoubtedly demonstrated 'values incompatible with the dominant feminine stereotype', according to Dunne's analysis. [40] It would seem then that many fifties' girls were encouraged to be sporty and daring as well as sedate and domestic, and that they were given a choice of role model denied to their daughters. Perhaps we should be asking what happened in the latter decades of the twentieth century to narrow reading options to a diet of fashion and romance.

In some respects the girl's weekly paper was transformed in the seventies and eighties into a junior version of the traditional woman's magazine, although most research into these publications has concentrated on the later twentieth century. [41] For the post-war years it has focused on general content and this suggests that sport and active leisure are almost entirely absent from both the standard weeklies and the 'quality' monthlies in the period 1946-56. Even She, launched in 1955 and aimed at 'the younger, enquiring 1950s' woman' covered everything from DIY to etiquette but still failed to mention sport. [42] Only three references have been found in Cynthia White's study of the genre to 1968: one noting the broadening of items in the 1950s to include careers, home entertaining and 'sports-coaching' (whatever this might mean), another concluding that increased affluence in the decade 1955-65 was allowing women to indulge in more expensive hobbies such as caravanning and sailing, a third quantifying the sports/recreation content of a selection of American women's magazines in 1967 at less than 2 per cent. [43]

There is, astonishingly, far greater coverage of women and sport in Victorian and Edwardian journals such as Womanhood and The Gentlewoman, catering for 
college-educated upper and middle-class women, than in the mass circulation post1945 weekly epitomised by Woman and Woman's Own. At the end of the nineteenth century the society journal Queen was confidently stating that 'the girls of the day are fine girls, handsome girls, well grown and well developed ... they are good for any number of games of tennis, they can row a good stroke on the river, they can paddle a canoe, they can make up an eleven at cricket.' [44] As Braithwaite points out, they came, of course, from the 'cossetted classes' but Catriona Parratt's study of Womanhood demonstrates that these were the very women who were challenging the dominant beliefs of the era. [45] Women's sport also features regularly in early twentieth-century publications such as the Badminton Magazine and Golf Illustrated, suggesting that the interests of many women were being addressed more extensively in 1905 than in 1955! The Badminton Magazine for 1913 included text and photos of women riding, showjumping, hunting (both foxes and otters), ski-ing, shooting, carriage driving, canoeing and sailing, fishing, and playing hockey, golf and croquet. The Gentlewoman for the same year also featured many of these together with swimming, skating and fencing. [46] Perhaps this implies an ongoing class distinction between the upper and middle-class women who read the quality Edwardian press, and whose participation in sports was increasingly tolerated, and the lower-middleclass or working-class woman who was most likely to read the popular 1950s' magazine. However, sport does not appear to feature in the glossy, more expensive monthlies of the fifties either; with titles such as Good Housekeeping and Woman and Home, it is clear where priorities lay. Editors probably knew that sport did not sell copy and excluded it for strictly commercial reasons, particularly when women, like men, could read about it in the back pages of newspapers or in specialist sports publications.

There is undoubtedly a danger in attempting to use the post-war commercial press as an indicator of the extent and significance of women's sport. As White points out, magazines in the period 1951-56 continued to reflect traditional domestic roles because the horizons of their readers were still very narrow and largely centred on the home. Even in the later fifties and early sixties when a wider range of leisure activities was featured in the popular women's press, sport was hardly mentioned. Weeklies in particular geared themselves to the lowest common denominator and were unwilling to upset their core readership. At the same time, however, a parallel universe was developing, consisting of an 'increasing number of women (who) were taking up occupations outside the home...(whose) needs were altogether ignored.' [47] Women with an interest in sport were similarly excluded by the conservative editorial policies of the traditional press. Is it likely that the more active, more modern reader would have any interest in magazines that took no account of their views, lifestyle or, in the case of the working mother, difficulties? Instead of focusing on the 5-6 million females who read these publications we should perhaps be reflecting instead on the 12-13 million of different ages, classes and wealth who did not, and for whom the traditional woman's magazine was an irrelevance. [48]

\section{Sport and gender in the post-war era: television}

Contrary to the evidence presented here, content analysis of newspaper articles at various periods has suggested that female sport was largely ignored or trivialised by the press; similar conclusions have been drawn from television coverage of sport. [49] An alternative assessment of the impact women's sport made on public consciousness 
might be determined by analysing the results of the annual BBC Sports Personality of the Year. Launched in 1954 as part of the popular BBC television sports magazine programme, Sportsview, these provide a different insight into how the viewing public rated sporting achievement and sports celebrities; the television accolade can be seen as a genuine endorsement by the British sporting public. It also furnishes the sole example of a sports award in which women are in direct competition with men.

Attitudes to what is now the annual BBC Sports Review of the Year, culminating in the Sports Personality award, have changed markedly in 55 years. Today cynical members of the press describe it as 'an orgy of self-congratulation dressed up in utter tweedom', complain about candidates of 'staggering mediocrity' and bemoan the fact that working-class heroes of fishing and darts have never won the prize - and are never likely to! In the more ingenuous fifties, the programme achieved a viewer approval rating of 85 and was apparently watched by 20 per cent of the adult population of Britain. [50] Its parent show, Sportsview, was short, novel, had been consciously aimed at a family audience and emphasised sporting personalities and the latest news in a slick presentation format; it quickly established itself as one of television's most popular features. The BBC Annual Report of 1954/55 boasted that every sporting personality of note had been interviewed in the course of the year; furthermore, the show made efforts to attract women viewers, even scheduling an entire programme devoted to women's sport. [51]

The inaugural Sports Personality award saw Empire Games gold medalwinning athlete Chris Chataway secure over one-third of the 14,500 votes (within four years the number of votes cast had risen to over 150,000). [52] He held off the challenge of record-breaker Roger Bannister, who in turn beat showjumper Pat Smythe by less than 500 votes. These two had been the winners of the Sporting Record sportsman and sportswoman awards; Smythe, an icon of middle-class girlhood, was a regular on BBC television as a result of its extensive coverage of showjumping in the 1950s. In the autumn of 1954 she and her horse Prince Hal had cleared $7 \mathrm{ft}$ 3ins $(2 \mathrm{~m} \mathrm{20} \mathrm{cm})$ to win the Ladies' European High Jump. [53]

It could be argued that programming choice and the visual impact of televised sport have a distorting effect on public votes. Chataway's win has been attributed in part to television coverage of his world-record breaking 5,000m run, in which he beat the European champion, Vladimir Kuts of Russia. [54]The race took place in October and was therefore far fresher in the public mind than Bannister's sub four-minute mile, achieved back in May; Smythe's record jump also took place shortly before the public vote. Such vagaries of the sporting calendar, together with the frailty of human memory, may well affect voting outcomes but all media communication is dependent on timing and on 'purchase' of the product, whether it be in print or broadcast form. Yet, the distorting impact of television scheduling may have been of little significance to the outcome of the Sports Personality contest as the same names generally featured in the annual rankings of all major sports awards of the era, though sometimes in a different order. [55]

There is no possibility of obtaining a gendered breakdown of votes; indeed the $\mathrm{BBC}$ only appears to have a complete voting record for a handful of years, and even the runners-up from 1955 to 1957 are unknown. All we have, therefore, are the bare results. [56] Nevertheless, an analysis of the votes over more than half a century has 
produced some interesting findings. Although Pat Smythe was the only successful woman in the 1950s, the following decade saw twelve females figure in the top three positions, including three consecutive winners (swimmer Anita Lonsbrough (1962), and athletes Dorothy Hyman (1963) and Mary Rand (1964). In 1962 women filled all three places (Dorothy Hyman second, swimmer Linda Ludgrove third), a feat never achieved since. Ann Jones, winner at Wimbledon, also picked up the main award in 1969. In the following thirty years, a paltry seven women were voted into the top three places and only the first decade of the twenty-first century shows signs of emulating the success of the 1960s, with ten women have been placed from 2000 to 2008. Taken at face value, this might suggest that the public profile of female athletes before 1970 was higher and that their achievements were accorded greater recognition than in any subsequent period.

It is difficult to know how to account for this as research by Garry Whannel has suggested that fewer women than men watch television sport. But in the 1950s the assumed audience model for sport included both genders, even if women were deemed to be novices and to have more interest in the players than the play. [57] It has already been noted that the BBC marketed Sportsview at a family audience and perhaps this might help to account for the success of female sports stars in the 1960s. It does not, however, explain why they were so spectacularly absent in later decades. Nor can it be assumed that women, then as now, will necessarily vote for other women: the success of sexy celebrity footballers such as Michael Owen and David Beckham, particularly in years when they have failed to achieve anything especially noteworthy on the pitch, suggests that there are many factors at work in the choice of Sports Personality of the Year.

Several possible interpretations of the results may be safely ignored. Although it could be argued that participants in individual rather than team sport were more likely to win the BBC award, perhaps favouring women, cricketer Jim Laker and footballer Bobby Charlton had previously come first and second. It seems unlikely that there was a dearth of suitable male candidates throughout British sport in the early 1960s - star sportsmen included Jimmy Greaves and Johnny Haynes from football, Fred Trueman and Ted Dexter in cricket, John Surtees, Jim Clark, Stirling Moss and Graham Hill from motor sport, Henry Cooper in boxing. The competition was advertised in gender neutral sites via BBC television and the Radio Times, but could it be that men were less interested in voting or that gaggles of schoolgirls sent in multiple votes (initially 'postcards only, please', then by way of a printed coupon) for their favourites? If this was indeed the case, why had Pat Smythe failed to win the trophy?

As for the unique result in 1962 it could be partly attributed to a non-Olympic year - the Olympics seemed to concentrate viewers' attention, resulting in medal winners carrying off the Sports Personality trophy in every Games year from 1960 to 1984. But in the immediate post-war decades the Empire Games, scheduled for even years within the Olympic cycle, also produced winners - Chataway in 1954, gold medal-winning swimmer Ian Black in 1958 and Anita Lonsbrough, triple gold medal winner in 1962. Second-placed Dorothy Hyman and third-placed Linda Ludgrove were each double gold medal winners at the 1962 Games. Furthermore, it cannot be argued that these winners had received an increased amount of television coverage as the Games took place in Perth, Australia, with all the limits that distance and time 
zones imposed on broadcasting. It would seem that these sportswomen were simply recognised as the best athletes that Britain produced that year.

None of this explains why female sports celebrities were so successful in the 1960s, or why they were virtually overlooked from 1972, when Olympic pentathlete Mary Peters picked up the trophy, to 1986 when javelin specialist Fatima Whitbread came second. Only two women, Wimbledon winner Virginia Wade and Jayne Torvill, one half of the Olympic gold medal-winning ice dance duo, were ranked during this period, as against 36 men (Torvill and Dean were voted first, then second in consecutive years). The question therefore remains as to why female sports celebrities failed to appeal to television audiences in the 1970s and 1980s. Moreover, the 1990s barely saw any improvement, Sally Gunnell being the sole representative of the years 1992-97. It appears that the television profile of sportswomen declined almost in parallel with the demise of the more 'tomboyish' girls' magazine.

\section{Some debates around women's sport in the post-war era - preliminary thoughts}

'Sport is cultural as well as physical, and what we do with our bodies is very much a product of what we think we ought to do with them.' [58]

Holt's observation seems particularly apposite when reflecting on women's sport. So much of what has been written revolves around perceptions of what is 'appropriate' for females, whether the discussion takes place in the media, in medicine, in education, within governing bodies, between men and women or amongst the public at large. As already noted many academics have chosen to emphasise negative attitudes to women's sport even when more positive views are known to be held, a matter that will be discussed further in this section. If one division of the press constructs sexist or belittling images of female athletes, certain members of the medical profession resurrect outmoded attitudes to competitive sport or some branch of sports governance advocates limited participation in strenuous physical exercise for women, sports historians and sociologists seem to assume that these were more important and more influential than contrary opinions. Even in the final years of the twentieth century, the post-war period has been assessed as one in which 'predominant assumptions about certain sports being appropriate and others being inappropriate have survived'. [59] But amongst whom? And, perhaps more importantly, what effect did they have on female participation in sport?

The success of Francina (Fanny) Blankers-Koen in the 1948 Olympics is a case in point. She was notoriously described in a Daily Graphic headline, 'Fastest woman in the world is an expert cook' in order, apparently, to position her as a suitably feminine role model, and the original quote in a pioneering book on women's sport has been replicated in a much respected history of post-war sport and society. [60] However, perhaps we should consider what other, more objective newspapers had to say. The Graphic, which had been merged with the Daily Sketch, was conservative in politics and populist in tone; certainly it and its sister paper were hardly known for their enlightened or liberal attitudes. In fact the British quality press printed entirely different headlines. The Daily Telegraph led with 'Blankers-Koen is female Jesse Owens': should we interpret this as a compliment to the Dutch athlete or will someone find some pejorative intent in this statement? The Times, which 
included photographs of three of her four victories, merely captioned the last with 'Another title for Mrs F. Blankers-Koen', a masterpiece of understatement. [61]

The almost ubiquitous view that sport for girls and women was restricted by press, public and medical opinion, may be further illustrated by a recent paper on post-war girl's magazines. It suggests that 'appropriate' physical activity was often a flashpoint in publications for girls and highlighted tensions for publishers as they sought both parental sanction and reader approval. As evidence for this difficulty, it then cites the problematic nature of girls' gymnastics and how articles in the national press had condemned sport as damaging for girls - but these references occurred at the end of the nineteenth century! [62] It is hard to imagine editors agonising about this issue in the 1950s, fully sixty years later: we have already seen that one, at least, took a relaxed and positive view of sporting opportunities for his readership.

Sportswomen themselves, across the entire class spectrum, have also indicated that they competed without reference to public opinion. Fencer Dame Mary Glen Haig represented Britain at the 1948 Olympics, reaching the final of the foil and winning a gold medal at the Empire Games of 1950. Asked if there were many opponents to women fencing at that time she replied, 'I think there were a lot of people like that, but it never bothered me, not at all.' [63] Britain's double Olympic track medallist in 1960, Dorothy Hyman, a working-class woman from a Yorkshire mining village, wrote in her autobiography, 'Running is a wonderful sport, and I get annoyed when I hear people criticising women's athletics as masculine and so on.' She was one of a dozen British female runners who won medals at Olympic or Empire Games in the fifties and early sixties, and returned home to public acclaim, 'the pride of the village'. [64]

It would seem, therefore, that research into women's sport over the past twenty years has been subject to a significant amount of 'cherry picking': selecting the 'facts' that best suit a particular hypothesis and applying a process of 'reverse research', in which scholars decide on the outcome they wish to achieve, and then seek out the evidence that would substantiate it. While this is not the place for a digression into Boothian textual analysis and the impossibility of achieving the objective stance, it is likely that feminist historians and their supporters, as a means of redressing a perceived imbalance, have selected the most telling, sometimes the most extreme, examples of bias against sportswomen in order to emphasise their argument. [65] Arguably, this approach frequently leaves the reader unsure of the strength of opposition to women's sport and, more significantly, unable to determine the extent to which it was effective. Furthermore, it is sometimes unclear whether the opposition was mere rhetoric or was sufficiently strong and co-ordinated to be able to materially hinder the development of women's participation in sport. In an era of limited media and other methods of communication, how and where did resistance to progress manifest itself, who undertook to prevent change and how could such impediments be enforced?

One example will have to suffice although others could be produced. In a discussion of interwar women's athletics, Jennifer Hargreaves tells us that the British Inter-University Athletics Board opposed women's athletics in 1919. Two years later we learn that students from Manchester University had formed a team; this was followed in 1923 by the establishment of the Women's Inter-Varsity Athletics Board. 
In other words, opposition to female student athletics was overcome within a very short period, at least in some areas. We are told on several occasions that there was hostility to women's athletics that could not be ignored because it came from 'some (my italics) authority figures from the public worlds of politics, medicine and education'; presumably some others felt otherwise as women continued to take part in athletic competition. [66] In an imperfect world there is seldom universal agreement about issues in society, and many in positions of power are able to generate the most hot air while not necessarily representing the majority view. Without in-depth research into the development of women's athletics after 1918, it is not possible to quantify the level of opposition or how successful it was. Lynne Duval's muchneglected paper clearly suggests that British women made substantial progress during this period in establishing athletics clubs and competitions, and that they often did so with the approval of the public at large and with considerable support from men [67]

The present study has also uncovered many instances of positive male influence, particularly from fathers and coaches. Anita Lonsbrough's father taught her to swim; Mary Glen Haig's father was a fencer and stimulated her interest in the sport; showjumper Dawn Palethorpe cited her father as her inspiration and her trainer. Dorothy Hyman candidly admitted that her father was the driving force behind her running: 'Dad always wanted boys ... but his boys weren't keen on sport. I was - so he trained me at sport almost as though $I$ were the boy.' Pat Smythe, Virginia Wade and Anneli Drummond-Hay all came from sporty families; both husbands and fathers have been acknowledged as central in developing female interest in golf; and in women's athletic clubs the positive and crucial role of male coaches can be nicely juxtaposed with the negativity and opposition of male officialdom in the guise of the IOC and International Amateur Athletic Federation. [68] While there were undoubtedly men - and some women - who disapproved of female sport, the importance of male support, particularly in domestic and club settings, should not be overlooked.

A further disputed issue is that of medical opinion. When feminist academics show that pseudo-medical arguments were used to legitimise opposition to women's sport, it is surely pertinent to ask the question who listened, particularly in an era of more limited media communication. There is ample evidence that some, largely upper and middle-class Victorian and Edwardian women, disregarded the restrictions that doctors, educators and not a few members of their own sex attempted to force on them, although it is less clear what impact professional advice had on those lower down the social scale. [69] In more modern times female athletes and their coaches were unlikely to be swayed by outmoded attitudes to womanhood. George Pallett, Vice President of Spartan Ladies A.C. and author of a manual on women's athletics in 1955 commented that

'the prejudiced could find medical support which suggested that running, jumping and throwing would do irreparable harm to the feminine frame... There cannot be found one recorded instance of a woman suffering lasting ill effects, of a nature which only a woman could sustain, by reason of participation in the sport.' [70]

Another athletics manual, first published in 1954 and updated in 1961 added further support 
With regard to women athletes, it is a fact that some countries will not allow women's races over $200 \mathrm{~m}$. This, however, has never been the case in Britain, where there are women's championships up to a mile on the track and $2 \frac{1}{2}$ miles over the country. It can be regarded as certain that running over these distances is not harmful for women - the very reverse in fact - always provided that (and this, of course, applies equally to men) they train properly and thoroughly before they start to race. This view, long held in Britain, is now gaining ground internationally and it is certain that the Olympic Games will soon include a women's championship at 800m.' [71]

Of the eleven strong British women's athletic team at the 1956 Olympics, four were married and at least two of these were mothers. Nor had motherhood prevented Fanny Blankers-Koen from winning four gold medals in 1948. The issue of male doctors and their perceived influence over female athletes is another aspect of women's sports history whose revision is overdue.

\section{Conclusion}

Female participation in sport and the ways in which it has been represented and understood are complex and contentious issues. Research to date has tended to focus on the late Victorian and Edwardian eras and on the final decades of the twentieth century, whereas the development of women's sport in the years following WWII has been largely neglected, even though British sportswomen were particularly successful at this time. Preliminary research certainly suggests that there were more positive aspects to women's experiences in the post-war period than we have been led to believe but that, for reasons yet to be fully explored, this 'window of opportunity' failed to stay open. One possible explanation for the curtailment of possibilities for sportswomen from the late 1960s is the death of amateurism and the rise of increasingly commercial forms of sport for men. [72] A great deal more research is needed.

Taking a revisionist approach to the subject, this paper has focused on previously under-utilised sources which show that neither the media nor the general public were overwhelmingly hostile or even indifferent to sport for women. The quality press, the $\mathrm{BBC}$ and a hitherto ignored magazine for girls have each been studied; all made efforts to highlight sporting opportunities, to include text and programming with sporting females in mind, and to celebrate the achievements of elite sportswomen in the fifties and sixties. Equally noteworthy is the fact that none trivialised or sexualised female athletes in the way we have been led to expect from analysis of more recent media coverage. One conclusion to be drawn from this research is that only a partial view of sports for women has been widely disseminated until now; there is much still to uncover. Another highlights the dangers of focusing exclusively on the populist press and 'traditional' women's magazines whose agenda and audience are likely to have been conservative.

Amongst the under-developed themes, three in particular stand out. The significance of the middle class in female sport merits further attention: middle-class girls may have been less easily 'persuaded' that sport was unfeminine and detrimental to their 
health and future careers as they were likely to have entertained ambitions beyond marriage and children, even if only for a short time. The role of men, especially family members and coaches, in supporting and encouraging both individuals and women's sports clubs, is a further area which seems to have been downplayed although there is ample written evidence of their assistance. [73] A third area of interest is that of perception: the way in which women's sport was perceived by the general public and how women saw themselves as athletes. The success of elite sportswomen in the BBC Sports Personality contest suggests a positive public attitude amongst viewers with an interest in sport. The indifference of female athletes to any public negativity expressed towards them reminds us that dedicated, talented women are unlikely to be dissuaded from their chosen course of action by the disapproval of others. Even Jennifer Hargreaves conceded that 'there has always been a small number of adventurous women who have transgressed gender roles.' [74] It matters little whether public attitudes are ambivalent.

Women's sport in the post-war era has been presented here in a different, and more positive, way in an effort to balance what has at times appeared to be a toostrident and politically-driven debate, much of which is now twenty years old. As Booth suggests, it is time to move away from the 'totalising, monolithic and homogenous cultural forms' of the past and to re-examine oppositional characteristics with fresh eyes. [75] Whilst few would deny the necessity for that original, pioneering discourse, it is certainly true that the writing of sport history in the twenty-first century might benefit from a more nuanced approach.

\section{Notes}

[1] Sport in History, 26 (2) (2006).

[2] http://www.bbc.co.uk/print/pressoffice/keyfacts/stories/spoty.shtml (accessed 2 June 2009)

[3] The Times, 5 December 1956.

[4] The standard text on women's sport in twentieth-century Britain emphasises the negative aspects of female participation - or lack of it - in the pre-1939 period and again during the 1970s and 1980s but has little to say about the immediate post-war decades. Jennifer Hargreaves, Sporting females: critical issues in the history and sociology of women's sports (London, 1994). The edited collection by Susan Birrell and Cheryl L. Cole, Women, Sport, and Culture (Champaign, IL, 1994), though largely featuring American sport, provides examples of the theories and perceptions typical of 1990s feminist scholarship.

[5] See, for example, Lynne Duval, 'The development of women's track and field in England. The role of the athletic club, 1920s-1950s', Sports Historian, 21 (1) (2001); Dorothy Hyman with Phil Pilley, Sprint to fame (London, 1964), p.48; www.news.bbc.co.uk/sport1/hi/olympics2000/bbc_team/859464.stm (accessed 2 March 2009)

[6] Calculated from data in Stan Greenberg, Whitaker's Olympic almanac (London, 2000) and the British Olympic Association, Summer Games at www.olympics.org.uk/gamesabout.aspx (accessed 17 February 2009)

[7] Lance Tingay, History of lawn tennis (London, 1973), p.125, 132, 142.

[8] Patricia Smyly, Anatomy of a show jumper: Anneli Drummond Hay (London, 1970), p.26. 
[9] Debby Sly, Badminton Horse Trials: the triumphs and the tears (Newton Abbot, 1999), pp.53-4; Smyly, Anatomy, p.22.

[10] Beryl Burton and Colin Kirby, Personal best: the autobiography of Beryl Burton (re-issue, Coventry, 2009); C. Nawrat, S. Hutchings \& G. Struthers, The Sunday Times illustrated history of twentieth century sport (London, 1995).

[11] For Curtis Cup see http://golf.about.com/od/teamcompetitions/p/curtis_cup.htm (accessed 3 March 2009); for Wightman Cup see Tingay, History of lawn tennis, p.135.

[12] Richard Holt and Tony Mason, Sport in Britain 1945-2000 (Oxford, 2000), note that in swimming 'it was women who made the bigger impact in the post-war years' (p.60) and that the 1960s saw 'the emergence of female athletics as a major force' (p.46). They also acknowledge, belatedly, the significance and undervaluing of the middle-class woman in sport. (p.9)

[13] Jennifer Hargreaves, as noted above, makes little mention of the period 194669; Martin Polley moves effortlessly from the 1948 Olympics to the mid-1960s (to be fair, he includes some neglected material on women in the minority sports of horseracing and equestrianism in the sixties). Hargreaves, Sporting females; Martin Polley, Moving the goalposts: a history of sport and society since 1945 (London, 1998), p.93, 96-7, 99.

[14] Duval, 'The development of women's track and field', p.11; Rosalynde Cossey, Golfing ladies (London, 1984), p.167 (I am grateful to Wray Vamplew for this reference); www.guardian.co.uk/sport/2008/jul/10/olympic games (accessed 17 February, 2009); www.bbc.co.uk/radio4/woman'shour/2004_18 thu 04.shtml (accessed 11 February, 2009).

[15] The Times, 18 June 1954.

[16] The Times, 19 October 1955.

[17] The Times, 13 August 1956. The identity of this 'anti-women athletes lobby' awaits further research.

[18] Daily Telegraph, 28 August 1960; Daily Telegraph, 5 December 1956.

[19] The Times, 1 December 1956; The Times, 4 June 1956; The Times, 22 July

1952. The 'arbitrary rule' forbade women members of showjumping teams. It was rescinded in time for the 1956 Games.

[20] For reporting of women's sport, see, for example, Mary Jo Kane \& Helen Jefferson Lenskyj, 'Media treatment of female athletes: issues of gender and sexualities' in Lawrence A. Wenner, ed., Media sport (London, 1998), pp.186-87; Hargreaves, Sporting females, p.194. For objectification/ sexualisation, see Hargreaves, p.162 and Margaret Carlisle Duncan \& Michael A. Messner, 'The media image of sport and gender' in Wenner, Media sport, pp.181-3. [21] Sports content is featured in Mary Dunne, 'An introduction to some of the images of sport in girls' comics and magazines' in Centre for Contemporary Cultural Studies, Sporting fictions (Birmingham,1982); Mel Gibson, "What became of Bunty?" The emergence, evolution and disappearance of the girls' comic in post-war Britain' in Morag Styles and Eve Bearne, eds., Art, narrative and childhood (Stokeon-Trent, 2003). General academic work includes Penny Tinkler, Constructing girlhood - popular magazines for girls growing up in England 1920-1950 (London, 1995); Brian Braithwaite, Women's magazines: the first 300 years (London, 1995); Cynthia L. White, Women's magazines 1693-1968 (London, 1970); Hargreaves, Sporting females, pp.149-50, 157-8.

[22] Dunne, 'An introduction', pp.39-40, 49. 
[23] Tinkler, Constructing girlhood, p.46.

[24] Gibson, 'What became of Bunty', p.88; Sally Morris and Jan Hallwood, Living with Eagles: Marcus Morris, priest and publisher (Cambridge, 1998), p.164;

Distribution of the population by sexes, Whitaker's Almanack (London, 1956), p.591. [25] Dunne, 'An introduction', p.57. Tinkler makes a similar point, noting that 'fiction heroines always conformed to the asexual ideal of the female adolescent.' Tinkler, Constructing girlhood, p.162.

[26] Morris, Living with Eagles, p.164, 169; Gibson, 'What became of Bunty', p.89.

[27] Morris, Living with Eagles, p.178, 164.

[28] Dominic Sandbrook, Never had it so good: a history of Britain from Suez to the Beatles (London, 2006), p.411.

[29] Gibson, 'What became of Bunty', n.1, p.99.

[30] Morris, Living with Eagles, p.166; Girl Annuals 1953-62, ed. Marcus Morris (London).

[31] Girl Annual (London, 1961), p.25.

[32] Girl Annual (London, 1962), p.125; Christine Truman, Tennis today, ed. Kenneth Wheeler (London, 1961).

[33] Girl Annual (London, 1959), p.80.

[34] Dunne, 'An introduction', p.58.

[35] Ibid., pp.48-9.

[36] See for example, Hargreaves, Sporting females, pp. 146-7.

[37] Girl Annual (London, 1954), p.22; Girl Annual (London, 1958), p.124.

[38] Truman, Tennis today, p.8; Virginia Wade with Mary Lou Mellace, Courting triumph (London, 1978), p.28.

[39] Girl Annual (London,1958), pp.122-25.

[40] Dunne, 'An introduction', p.38.

[41] Hargreaves, Sporting females, p.290.

[42] White, Women's magazines, pp.125-130; Braithwaite, Women's magazines, p.68.

[43] White, Women's magazines, p.140, 156, 246-7. White particularly notes the conservatism of women's magazines in 1950s America and flags up the issue of difference/similarity on either side of the Atlantic. The extent to which British women in general, women's sport in Britain, and British sports historians and sociologists have been influenced by attitudes, arguments and ideas originating in the United States is a potentially significant topic in its own right. I intend to pursue it over the coming months.

[44] Braithwaite, Women's magazines, p.24.

[45] Ibid; Catriona Parratt, "Athletic "Womanhood": Exploring sources for female sport in Victorian and Edwardian England', Journal of Sport History, 16 (2) (1989), p.141.

[46] Joyce Kay, "No time for recreations till the vote is won?" Suffrage activists and leisure in Edwardian Britain', Women's History Review, 16 (4) (2007), pp.540-43. [47] White, Women's magazines, p.151.

[48] Based on sales figures for top magazines in late 1950s - Braithwaite, Women's magazines, p.71; total population figures from 1951 census, age range 15-69, Whitaker (1956), p.590.

[49] See, for example, Duncan \& Messner, 'The media image of sport and gender', p.173. 
[50] Kevin Mitchell, The Observer, 16 July 2006; Steve Rider with Martyn Smith, BBC Sports Personality of the Year (London, 2003), p.12; Asa Briggs, The history of broadcasting in the United Kingdom, Vol. IV (Oxford, 1979; this edition 1995), p.776.

[51] Garry Whannel, Fields in vision: television sport and cultural transformation (London, 1992), p.39; Briggs, History of broadcasting, p.774.

[52] Rider, BBC Sports Personality, p.11.

[53] Pat Smythe, Jump for joy (London, 1955), p.239.

[54] Rider, BBC Sports Personality, p.11; Whannel, Fields in vision, p.152.

[55] For comparison, see

www.sportsjournalists.co.uk/awards_sports.php?content=winners (accessed 3 March, 2009)

[56] Both Rider, BBC Sports Personality and the Sports Personality website (see note 2) confirm that no record of second and third places survives.

[57] Garry Whannel, 'Reading the sports media audience' in Lawrence A. Wenner, ed., Media sport (London, 1998), p.222.

[58] Richard Holt, Sport and the British: a modern history (Oxford, 1989), p.3.

[59] Polley, Moving the goalposts, p.104.

[60] Adrianne Blue, Grace under pressure: the emergence of women in sport (London, 1987), p.72; Polley, Moving the goalposts, p.93.

[61] Daily Telegraph, 4 August 1948; The Times, 7 August 1948.

[62] Gibson, "What became of Bunty?", p.89.

[63] www.guardian.co.uk/sport/2008/jul/10/olympic games. Accessed 17 February, 2009.

[64] Hyman, Sprint to fame, p.143, 48.

[65] Douglas Booth, The Field; Truth and fiction in sport history (London, 2005), pp.118-22.

[66] Hargreaves, Sporting females, pp.131-33.

[67] Duval, 'The development of women's track and field', pp.9-18.

[68] www.times-olympics.co.uk/british winners/swimming.html (accessed 2

March, 2009); www.guardian.co.uk/sport/2008/jul/10/olympic games;

www.worcesternews.co.uk (accessed 20 February, 2009); Hyman, Sprint to fame, p.86; Jane George, 'Women and golf in Scotland' (unpublished PhD. thesis, University of Edinburgh, 2003), p.77 (I am grateful to Jane George for this reference); Duval, 'The development of women's track and field', pp.16-18.

[69] Parratt, "Athletic "Womanhood", p.141.

[70] George Pallett, Women's athletics (Dulwich, 1955), pp.13-14.

[71] F.N.S. Creek, Teach yourself athletics (London, 1961), p.46.

[72] An idea touched on briefly by Holt and Mason, Sport in Britain, p.46.

[73] See note 68.

[74] Jennifer Hargreaves, Heroines of Sport: the politics of difference and identity (London, 2000), p.2.

[75] Booth, The Field, p.139. 
